\title{
Do Donors Care About Declining Trade Revenue from Liberalization? An Analysis of Bilateral Aid Allocation
}

\author{
Javed Younas and Subhayu Bandyopadhyay
}

\begin{abstract}
Many developing-country governments rely heavily on trade tax revenue. Therefore, trade liberalization can be a potential source of significant fiscal instability and may affect government spending on development activities-at least in the short run. This article investigates whether donors use aid to compensate recipient nations for lost trade revenue or perhaps to reward them for moving toward freer trade regimes. The authors do not find empirical evidence supporting such motives. This is of some concern because binding government revenue constraints may hinder development prospects of some poorer nations. The authors use fixed effects to control for the usual political, strategic, and other considerations for aid allocations. (JEL F35, H0)
\end{abstract}

Federal Reserve Bank of St. Louis Review, May/June 2009, 91(3), pp. 141-53.

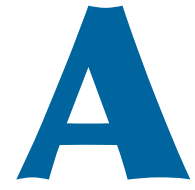

fter successive Uruguay Round negotiations and the creation of the World Trade Organization in the 1990s, many developing countries chose to dismantle their trade barriers and open their economies to international competition. Transition to free trade may involve substantial short-run costs for developing governments, especially in terms of a decline in tax revenues. Many developing countries rely heavily on trade tax revenue, and a reduction or elimination of these taxes may be a source of their fiscal instability. To the extent that public spending is targeted at useful programs (e.g., schools, infrastructure, health), the transition to free trade initially may result in a significant loss for a poor nation. In the long run, if liberalization is successful, these problems would be expected to be addressed both by provision of better private markets and rising revenues from different sources (income and sales taxes or possibly trade taxes owing to the volume effect) as a result of rising national income levels. However, even in the case of potentially successful liberalization, the donors may be concerned about the short-run budgetary implications of trade liberalization for the poorest of nations.

In principle, even in the short run, revenue losses from trade liberalization may be offset by turning to less-distortionary alternative sources of revenue. This approach requires good governance and an efficient domestic tax system; however, the evidence for this alternative is somewhat disheartening. For example, Baunsgaard and Keen (2005) argue that middle- and low-income countries fail to achieve substantial tax reforms to replace the lost trade revenue by revenue from other sources. They find that middle-income countries recovered 45 to 60 cents from other sources for every one-dollar loss in trade tax revenue, whereas low-income countries could recover no more than 30 cents for each lost dollar. Khattry

Javed Younas is a visiting assistant professor in the Department of Economics at Central Michigan University. Subhayu Bandyopadhyay is a research officer and economist at the Federal Reserve Bank of St. Louis and a research fellow at the Institute for the Study of Labor (IZA), Bonn, Germany. The authors thank Howard Wall for several helpful comments and suggestions.

(C) 2009, The Federal Reserve Bank of St. Louis. The views expressed in this article are those of the author(s) and do not necessarily reflect the views of the Federal Reserve System, the Board of Governors, or the regional Federal Reserve Banks. Articles may be reprinted, reproduced, published, distributed, displayed, and transmitted in their entirety if copyright notice, author name(s), and full citation are included. Abstracts, synopses, and other derivative works may be made only with prior written permission of the Federal Reserve Bank of St. Louis. 
and Rao (2002) find that in low-income countries revenue constraints remain even after a decade of trade reforms, and they emphasize the need for a fiscally realistic development strategy in the postliberalization period. In a broader analysis of the limitations of trade policy reform in developing countries, Rodrik (1992) argues that tariff reduction at the cost of fiscal considerations can have disastrous consequences. He cites the examples of Turkey and Morocco, where trade taxes were reimposed because of fiscal problems.

The logic of compensating trade-liberalizing developing nations is consistent with the foreign aid objectives of reducing poverty and promoting economic development, captured in the Development Assistance Committee (DAC) guidelines for poverty reduction of the Organisation for Economic Co-operation and Development (OECD). ${ }^{1}$ Moreover, donor nations may also be driven by the motivation to pursue their own economic interests in their potential export markets (see Dudley and Montmarquette, 1976; Neumayer, 2003; and Younas, 2008). Indeed, aid in "bailing out" liberalizing nations may also relate to the self-interest motive outlined in these contributions. Donors may worry that fiscal crisis may halt or reverse trade liberalization, which would not benefit the donors' export interests. Therefore, to maintain trade relations, they may compensate developing nations that experience a decline in trade tax revenues. ${ }^{2}$

Despite the sizeable literature in this broad area of trade and foreign aid, empirical analysis of the impact of trade liberalization and declining trade revenues on foreign aid allocation is sparse. ${ }^{3}$ Most studies focus on the political and strategic interests of donors; others analyze their developmental and humanitarian concerns; and some investigate both aspects. ${ }^{4}$ Recent studies

\footnotetext{
1 For example, see the guidelines at www.oecd.org/dataoecd/47/ 14/2672735.pdf.

2 Bagwell and Staiger (2001) analyze reciprocal and mutually advantageous trade liberalization agreements.

3 There are, however, some theoretical contributions on this issue. For example, Lahiri and Raimondos-Møller (1997) present a model in which recipient nations compete to give tariff concessions to donors to receive a larger share of foreign aid.

4 See, for example, McKinlay and Little (1977 and 1979), Maizels and Nissanke (1984), Dowling and Hiemenz (1985), Trumbull and
}

have explored other aspects of donors' aid allocation, such as colonial ties of aid-recipient countries and support to donor countries in U.N. voting (Alesina and Dollar, 2000; Burnside and Dollar, 2000; and Kuziemko and Werker, 2006). Dollar and Levin (2004) find that overall more aid has been allocated to poor countries that have reasonably good economic governance. They find, however, that this pattern is somewhat different between bilateral and multilateral donors. We complement the literature by empirically investigating the effect of declining trade revenue on aid allocation decisions.

We estimate the effects of revenue collection (from import duties and international trade taxes) on aggregate bilateral aid allocation given by 22 DAC-member countries of the OECD to 52 aidrecipient countries over the 1991-2003 period. ${ }^{5}$ We use fixed effects to control for the usual political, strategic, and other considerations for aid allocations. Our central finding is that there is no statistically significant evidence that supports the hypothesis that donors compensate for trade revenue losses of the recipients.

The remainder of the paper is organized as follows. The next section provides the empirical model and methodology, followed by the data description section. The third section presents the estimation results, and the final section contains our summary and conclusion.

\section{THE EMPIRICAL MODEL AND METHODOLOGY}

Three goals guide our sample selection. First, we include only middle- and low-income aidrecipient countries because past studies conclude that they face the highest uncompensated loss of tax trade revenue from trade liberalization

\footnotetext{
Wall (1994), Wall (1995), Neumayer (2003), and Bandyopadhyay and Wall (2007).

5 The sample of aid-recipient countries is constrained by the nonavailability of consistent yearly data, and most data are available only for years after 1990. Since many studies find that containment of communism rather than development concerns was a major factor for providing aid during the Cold War era, we limit our analysis to the post-Cold War period (see Boschini and Olofsgård, 2007).
} 
(Baunsgaard and Keen, 2005; Khattry and Rao, 2002; Rodrik, 1992). ${ }^{6}$ Second, we exclude Israel and Egypt from the data because both countries receive a disproportionately higher amount of aid from the United States, largely based on their strategic locations in the Middle East. Third, we limit our analysis to the post-Cold War period because containment of communism rather than development concerns was a major factor for providing aid during the Cold War era (see Boschini and Olofsgård, 2007).

Our empirical model of bilateral aid from 22 DAC-member countries of the OECD to 52 aidrecipient countries takes the following form:

(1)

$$
\begin{aligned}
& \ln (\text { baid })_{i t}=\beta_{0}+\beta_{1} \ln (\text { pop })_{i t}+\beta_{2}\left[\ln (\text { pop })_{i t}\right]^{2} \\
& +\beta_{3} \ln (\text { inc })_{i t}+\beta_{4}\left[\ln (\text { inc })_{i t}\right]^{2}+\beta_{5} \ln (\text { mor })_{i t} \\
& +\beta_{6} \ln (\text { rights })_{i t}+\beta_{7} \ln (\text { imd })_{i t}+\beta_{8} \ln (\text { ttr })_{i t} \\
& +\beta_{8} \ln (\text { maid })_{i t}+\beta_{i}+\lambda_{t}+\mu_{i t} .
\end{aligned}
$$

where $i=$ aid-recipient countries, $t=$ years, and the following apply to each recipient country:

$$
\begin{aligned}
& \text { baid = total real bilateral aid } \\
& \text { pop = population size } \\
& \text { inc }=\text { per capita income } \\
& \text { mor }=\text { the infant mortality rate } \\
& \text { rights = level of political rights and civil } \\
& \text { liberties } \\
& \text { imd = real revenue from import duties } \\
& \text { ttr }=\text { real revenue from international trade } \\
& \text { taxes } \\
& \text { maid = total real multilateral aid } \\
& \beta_{i}=\text { recipient-specific fixed effects } \\
& \lambda_{t}=\text { year dummy variables } \\
& \mu_{i t}=\text { error term }
\end{aligned}
$$

Aid and per capita income may be either substitutes or complements. They will be substi-

6 The World Bank (2006) classifies aid-recipient countries into high-income non-OECD, middle-income, and low-income countries.

7 Revenue from international trade taxes and from import duties is not included simultaneously in the regression because of very high correlation between them. tutes if compassion or altruism is the driving force. In this case, more aid is given when per capita income falls. In addition, we also introduce a squared term for per capita income to determine whether this effect increases for poorer nations. Population is included to capture the difference in recipient-country size (Bandyopadhyay and Wall, 2007). The sign of its coefficient will suggest whether a population-related bias exists in aid allocation.

Per capita income alone may not be an adequate reflection of economic need, especially in view of high income inequalities in several recipient countries. This prompted our use of the infant mortality rate, which relates to the concept of individual well-being. This variable is also used in the existing literature as a measure of a nation's well-being (Trumbull and Wall, 1994; Wall, 1995; Bandyopadhyay and Wall, 2007; Younas, 2008). ${ }^{8-10}$ The political rights and civil liberties variable, which is used as a proxy for human rights, captures the donor's perception of the objective function of the recipient government: If a recipient government values human rights, the perception may be that it puts a higher weight on its peoples' welfare and would use the aid to improve their well-being.

We expect to see a negative relation between revenue from international trade taxes (or from import duties) and aid if donors either (i) compensate for revenue losses from trade liberalization or (ii) reward the nations that engage in such liberalization. We note, however, that these two motives are distinct in principle but observationally equivalent. Following Younas (2008) we also include real multilateral aid to a recipient

8 The World Bank (2006) defines the infant mortality rate as the number of infants who die before 1 year of age per 1,000 live births in a given year.

9 Per capita income captures economic needs, whereas infant mortality signifies physical needs (Trumbull and Wall, 1994; Wall, 1995; and Bandyopadhyay and Wall, 2007). Bandyopadhyay and Wall (2007) note that although economic and physical needs are clearly correlated in the long run, they do not necessarily move in the same direction over shorter periods.

${ }^{10}$ Correlations among the independent variables are not high, with the exception of that between per capita income and the infant mortality rate. To check whether multicollinearity poses a problem, eigenvalues for correlations among explanatory variables were tested and found to be low. 
country. ${ }^{11}$ Bilateral and multilateral aid may be either substitutes or complements. They will be substitutes if donor nations reduce their aid allocation to a recipient that also receives aid from multilateral agencies. They will be complements if donor nations provide more aid to maintain their political influence on a recipient.

To control for the usual political, strategic, and other considerations for aid allocations by donors, we introduce recipient-specific fixed effects in the model. Finally, we include time dummy variables that are common to all aid recipients within a given year. Time dummies control for events such as a flood or a drought within a particular year, which may lead to an aid spike for the corresponding year. ${ }^{12}$ Moreover, all regressions are estimated using feasible generalized least squares allowing for recipient-specific heteroskedasticity.

Because most explanatory variables vary across a wide range (such as population size, per capita income, international trade tax revenue, and revenue from import duties) and exhibit skewed distributions, we use the natural log of all variables. Also, we use a log-log model to help reduce outlier effects, and the resulting coefficients are interpreted as elasticities.

Before proceeding to estimation, we address the possibility of simultaneous causation between aid and per capita income. It may be argued that per capita income of a recipient may be endogenous because it not only affects the donor's decision to provide aid but also may be affected by the flow of aid. ${ }^{13}$ Wooldridge (2003) states that if we assume that the error term, $\mu_{i t}$, is uncorrelated (a standard assumption) with all past endogenous and exogenous variables, then lagged endogenous variables in simultaneous models are treated as

\footnotetext{
${ }^{11}$ The multilateral aid is given by the World Bank, the International Monetary Fund (IMF), and the United Nations, including their regional branches.

12 Inclusion of time-specific dummy variables allows each time period to have its own intercept for aggregate time effects that affect all recipients. Also, one time-specific dummy must be dropped to avoid perfect collinearity. We also drop one recipient-specific dummy in the fixed effects model for the same reason.

${ }^{13}$ Most literature on aid shows that aid does not cause growth. Thus, there is little reason to believe that there would be reverse causation from aid to per capita income.
}

predetermined variables and are uncorrelated with $\mu_{i t}{ }^{14}$ Following that technique, we use a 1year-lagged value for all independent variables in our econometric model. This makes sense as information to the donors about a recipient is available only with some time lag (Younas, 2008). Thus, our empirical model in equation (1) takes the following form:

(2)

$$
\begin{aligned}
& \ln (\text { baid })_{i t}=\beta_{0}+\beta_{1} \ln (\text { pop })_{i, t-1}+\beta_{2}\left[\ln (\text { pop })_{i, t-1}\right]^{2} \\
& +\beta_{3} \ln (\text { inc })_{i, t-1}+\beta_{4}\left[\ln (\text { inc })_{i, t-1}\right]^{2}+\beta_{5} \ln (\text { mor })_{i, t-1} \\
& +\beta_{6} \ln (\text { rights })_{i, t-1}+\beta_{7} \ln (\text { imd })_{i, t-1}+\beta_{8} \ln (t t r)_{i, t-1} \\
& +\beta_{8} \ln (\text { maid })_{i, t-1}+\beta_{i}+\lambda_{t}+\mu_{i t} .
\end{aligned}
$$

\section{DESCRIPTION OF DATA}

The data for aggregate net bilateral aid to 52 recipient countries for the 1992-2003 period are from OECD International Development Statistics (OECD, 2005). ${ }^{15}$ The data contain aid given for development purposes only and do not include grants, loans, and credits for military purposes. ${ }^{16}$ Data for multilateral aid are also from the same source.

Data for revenue from international trade taxes and import duties are from Government Finance Statistics (International Monetary Fund [IMF], 2005) and World Development Indicators

\footnotetext{
${ }^{14}$ Maizels and Nissanke (1984), while citing Maddala (1977), state that "all estimation techniques, including 2SLS [two-stage least squares], are designed to deal only with the contemporaneous simultaneity and the lagged endogenous variables are treated in simultaneous models as predetermined variables along with other exogenous variables in the system." Therefore, if aid flows can be assumed to affect a country's economic performance with some time lag, the problem of simultaneous bias is considerably lessened.

${ }^{15}$ Bilateral aid is from 22 DAC-member countries of the OECD (Australia, Austria, Belgium, Canada, Denmark, Finland, France, Germany, Greece, Ireland, Italy, Japan, Luxembourg, Netherlands, New Zealand, Norway, Portugal, Spain, Sweden, Switzerland, United Kingdom, and the United States). Eight aid-recipient countries in our dataset received no aid or negative aid (net payer) for 1 or a maximum of 2 years in the 12 yearly time periods in our sample. We placed a value 0 for such observations.

${ }^{16}$ Following Neumayer (2003) and Younas (2008), we converted the aid data into constant year-2000 U.S. dollars using the unit value of the world import price index; data are from the United Nations Conference on Trade and Development (2005).
} 
([WDI], World Bank, 2006). The revenue data are given in the national currency of each country. We have converted these data into U.S. dollars using the exchange rate for each country for each year. ${ }^{17}$ As we did for the aid data, we also converted international trade tax revenue and import duties into constant year-2000 U.S. dollars using the unit value of the world import price index. ${ }^{18}$ The data appendix shows the countries' average data on trade tax revenue variables, both in levels and also as ratios of total tax revenue. According to WDI (World Bank, 2006), taxes on international trade include import duties, export duties, profits of export or import monopolies, exchange profits, and exchange taxes, whereas import duties comprise all levies collected on goods at the point of entry into the country. The levies may be imposed for revenue or protection purposes and may be determined on a specific or ad valorem basis, as long as they are restricted to imported products. ${ }^{19}$

Per capita income is measured by per capita gross domestic product (purchasing power parity) at constant year-2000 U.S. dollars. Data for per capita GDP, population, and infant mortality rates are obtained from WDI (World Bank, 2006). ${ }^{20} \mathrm{We}$ use indices for political rights and civil liberties produced by Freedom House (2006) as a proxy for human rights measure. "Political rights" refer to the freedom of people to participate in the political process by exercising their voting rights, the right to organize political parties to compete for

${ }^{17}$ Data for exchange rates are from International Finance Statistics (IMF, 2004).

${ }^{18}$ A few countries in our sample do not have complete observations for revenue from international trade taxes and import duties for all 12 yearly time periods.

${ }^{19}$ Because it cannot be stated with certainty that a decline in trade tax revenue is always the consequence of trade liberalization, we regressed the ratio of trade tax revenue to total tax revenue on the trade openness index devised by Sachs and Warner (1995). In addition, we used the economic globalization index of Dreher (2006). The results show that both trade openness and economic globalization cause a decline in trade tax revenue in developing countries (these results are available from the authors on request). Although these findings may not be conclusive, our study mainly aims to analyze whether donor countries compensate recipient countries for declining trade tax revenue.

${ }^{20}$ Some data values are missing for some countries for infant mortality rates. Because infant mortality rates change slowly over time, values for missing observations are interpolated by calculating averages from available values. public office, and the ability to form an effective opposition and elect representatives who devise public policies and are accountable for their actions. "Civil liberties" entail the freedom of expression and religious belief, the prevalence of rule of law, the right to form unions, the freedom to marry, and the freedom to travel. It also signifies the autonomy of citizens without interference from the state. These two indicators are derived from a cross-country survey every year. Each of these indices is measured on a scale from 1 (best) to 7 (worst) points. Following the literature on aid (see, for example, Trumbull and Wall, 1994; Wall, 1995; Neumayer, 2003; and Younas, 2008), we constructed a combined freedom index by adding indices of political rights and civil liberties, and then reverted that index so that it ranges from 2 (worst) to 14 (best) points.

Figures 1 and 2 show the correlations between real bilateral aid and revenue from international trade taxes and revenue from import duties, respectively. The correlation pattern gives a crude idea that aid is concentrated mostly toward recipients with low revenue from import duties and international trade taxes. The correlation pattern of bilateral aid and ratios of revenue from international trade taxes to total tax revenue and the ratio of revenue from import duties to total tax revenue in Figures 3 and 4 also seem to suggest a somewhat similar pattern.

\section{RESULTS}

The correlations suggest higher aid allocation to countries experiencing a decline in international trade revenues. To ascertain the existence of any significant econometric relationship, we run regressions by simultaneously controlling for all explanatory variables in our model to find their individual effects on aid.

\section{Model without Fixed Effects}

We first estimate the model under the restriction that fixed effects for donors' considerations for aid allocations do not matter $\left(\beta_{i}=0 \forall_{i}\right)$. All regressions are estimated using feasible generalized least squares allowing for recipient-specific heteroskedasticity. The results are presented in 


\section{Figure 1}

\section{Correlation Between Aid and Revenue from Import Duties}

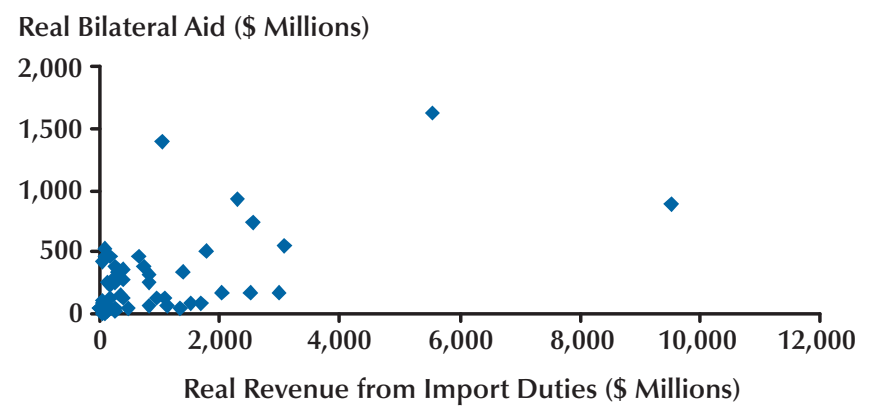

\section{Figure 2}

\section{Correlation Between Aid and Revenue from International Trade Taxes}

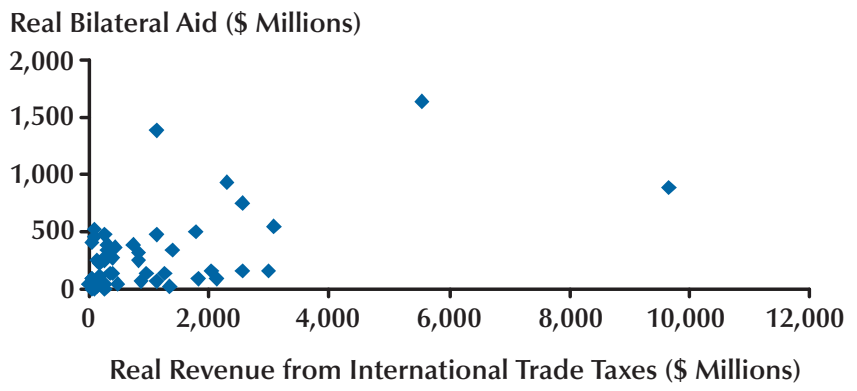

columns 1 and 2 of Table 1 . Surprisingly, the effect of the key variable of interest-revenue from import duties-is positive and statistically significant at the 10 percent level. This peculiar result is somewhat confusing as it seems to suggest that more aid goes to recipients experiencing an increase in trade tax revenue. However, we cannot rely on this result because without controlling for fixed effects, the estimates will be biased and inconsistent. This effect can be more prevalent in our study because past literature reports on aid conclude that bilateral donors' political, strategic, and other considerations also determine their aid allocation decisions for such countries.

On the other hand, the impact of all other variables except political rights and civil liberties is statistically different from zero. According to $t$ statistics, their coefficients are significant at the 1 percent level. The hill-shaped relationship between aid and population suggests a bias in aid allocation toward less-populated developing countries (Bandyopadhyay and Wall, 2007). This also implies that countries such as India, China, and Pakistan remain at a disadvantage in garnering more aid because of their large populations. Per capita income and infant mortality rates appear to be important indicators of bilateral aid allocation. A 1 percent increase in the infant mortality rate has an impact of a 0.24 percent increase in aid allocation. The positive but quadratic relationship between aid and per capita income sug- 
Figure 3

\section{Correlation Between Aid and Ratio of Revenue from Import Duties to Total Tax Revenue}

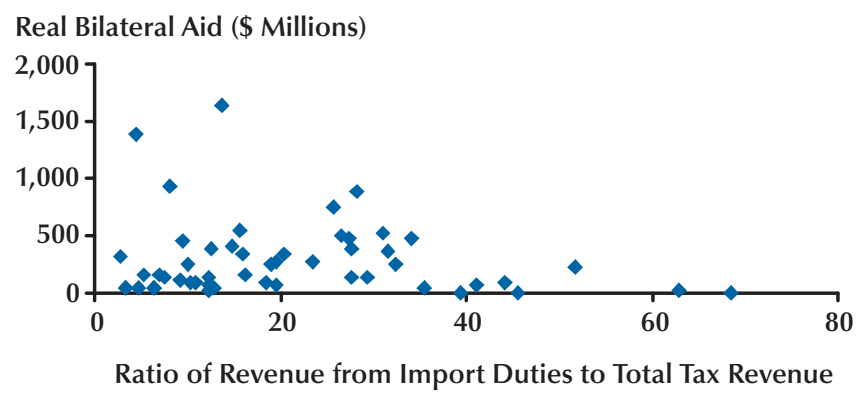

\section{Figure 4}

\section{Correlation Between Aid and Ratio of Revenue from International Trade Taxes to Total Tax Revenue}

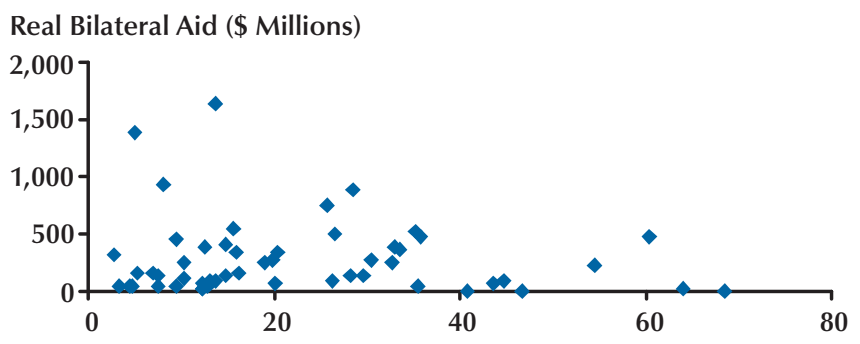

Ratio of Revenue from International Trade Taxes to Total Tax Revenue

gests that the donors do not favor the poorest of developing nations, although this pattern is reduced toward the higher end of the income scale. The level of aid is not responsive to political rights and civil liberties.

The positive and significant coefficient on multilateral aid suggests that donor countries provide more aid to recipient countries that also receive aid from multilateral agencies. ${ }^{21}$ This result is also consistent with a previous finding (Younas, 2008). Omitting revenue from import duties from the regression and including revenue

${ }^{21}$ Because bilateral donors provide funds to multilateral agencies (e.g., World Bank, IMF, United Nations), their likely influence over aid allocation decisions of these agencies may also be a factor that affects this result. from international trade taxes yields similar results (Table 1, column 2).

\section{Model with Fixed Effects}

Now we estimate the model without imposing the restrictions that the fixed effects are all zero (columns 3 and 4 of Table 1). This is the preferred model because it controls for the donors' usual political, strategic, and other considerations of aid allocations. We find that only per capita income, its squared term, and multilateral aid are statistically significant. Trade revenue variables are statistically insignificant in both of the fixed-effects regressions. This suggests that donors do not appear to consider recipients' trade revenue levels in their aid allocation decisions. 


\section{Table 1}

\section{Dependent Variable: In(Bilateral aid)}

\begin{tabular}{|c|c|c|c|c|}
\hline \multirow[b]{2}{*}{ Independent variables } & \multicolumn{2}{|c|}{ Without fixed effects } & \multicolumn{2}{|c|}{ With fixed effects } \\
\hline & [1] & [2] & [3] & [4] \\
\hline In(Population) & $\begin{array}{l}0.972 \\
(4.67)^{* * *}\end{array}$ & $\begin{array}{l}0.925 \\
(4.40)^{* * *}\end{array}$ & $\begin{array}{c}1.952 \\
(0.71)\end{array}$ & $\begin{array}{c}1.969 \\
(0.69)\end{array}$ \\
\hline$[\ln (\text { Population })]^{2}$ & $\begin{array}{l}-0.019 \\
(3.11)^{* * *}\end{array}$ & $\begin{array}{l}-0.017 \\
(2.85)^{* * *}\end{array}$ & $\begin{array}{c}-0.140 \\
(1.55)\end{array}$ & $\begin{array}{c}-0.148 \\
(1.61)\end{array}$ \\
\hline In(Per capita income) & $\begin{array}{l}6.254 \\
(7.49)^{* * *}\end{array}$ & $\begin{array}{l}6.062 \\
(7.24)^{* * *}\end{array}$ & $\begin{array}{l}11.714 \\
(4.93)^{* * *}\end{array}$ & $\begin{array}{l}11.825 \\
(4.86)^{* * *}\end{array}$ \\
\hline [In (Per capita income) $]^{2}$ & $\begin{array}{l}-0.408 \\
(7.57)^{* * *}\end{array}$ & $\begin{array}{l}-0.397 \\
(7.35)^{* * *}\end{array}$ & $\begin{array}{l}-0.784 \\
(5.14)^{* * *}\end{array}$ & $\begin{array}{l}-0.796 \\
(5.11)^{* * *}\end{array}$ \\
\hline In(Infant mortality) & $\begin{array}{l}0.244 \\
(3.04)^{* * *}\end{array}$ & $\begin{array}{l}0.215 \\
(2.61)^{* * *}\end{array}$ & $\begin{array}{c}0.033 \\
(0.13)\end{array}$ & $\begin{array}{c}0.039 \\
(0.15)\end{array}$ \\
\hline In(Political and civil rights) & $\begin{array}{c}0.045 \\
(0.63)\end{array}$ & $\begin{array}{c}0.055 \\
(0.77)\end{array}$ & $\begin{array}{c}-0.113 \\
(0.79)\end{array}$ & $\begin{array}{c}-0.105 \\
(0.74)\end{array}$ \\
\hline In(Import duties revenue) & $\begin{array}{c}0.059 \\
(1.81)^{*}\end{array}$ & - & $\begin{array}{c}0.059 \\
(0.88)\end{array}$ & - \\
\hline In(International trade tax revenues) & - & $\begin{array}{c}0.067 \\
(2.02)^{* *}\end{array}$ & - & $\begin{array}{c}0.069 \\
(0.96)\end{array}$ \\
\hline In(Multilateral aid) & $\begin{array}{l}0.154 \\
(5.70)^{* * *}\end{array}$ & $\begin{array}{l}0.146 \\
(5.32)^{* * *}\end{array}$ & $\begin{array}{l}0.074 \\
(3.17)^{* * *}\end{array}$ & $\begin{array}{c}0.075 \\
(3.26)^{* * *}\end{array}$ \\
\hline Recipient fixed effects & No & No & Yes & Yes \\
\hline Year dummies & Yes & Yes & Yes & Yes \\
\hline Estimated coefficients & 20 & 20 & 71 & 71 \\
\hline Wald chi-square & $1,121.94$ & $1,084.11$ & $3,433.25$ & $3,408.02$ \\
\hline Log likelihood & -767.10 & -766.62 & -550.42 & -552.62 \\
\hline Observations & 555 & 555 & 555 & 555 \\
\hline
\end{tabular}

NOTE: Estimated using feasible generalized least squares allowing for recipient-specific heteroskedasticity. ${ }^{* * *},{ }^{* *}$ and ${ }^{*}$ indicate significance at the 1, 5, and 10 percent levels, respectively. See text for detailed explanations of columns 1 through 4.

This evidence is somewhat disheartening because past studies have found that most revenue losses from international trade taxes in developing countries are not compensated from other domestic sources (Baunsgaard and Keen, 2005; Khattry and Rao, 2002; Rodrik, 1992). The likelihood-ratio test also rejects the null hypothesis that the fixed effects are all zero, implying that this is the statistically superior model. It is also the preferred model because it controls for donors' usual political, strategic, and other considerations of aid allocations.

As a robustness check, we also derive the estimation from another angle. It is possible that donors may consider the ratio of revenue from import duties to total tax revenue and/or the ratio of revenue from international trade taxes to total tax revenue in making aid allocation decisions. For this purpose, we omit the revenue variables in levels and include the ratios (see Table 2). Interestingly, the findings without fixed effects for both import duties and international trade taxes in ratios now show the expected negative sign and that they are also statistically significant (columns 1 and 2). However, when we introduce fixed effects in this context, we again find no significant relation (columns 3 and 4). Based on 
Table 2

Dependent Variable: In(Bilateral aid)

\begin{tabular}{|c|c|c|c|c|}
\hline \multirow[b]{2}{*}{ Independent variables } & \multicolumn{2}{|c|}{ Without fixed effects } & \multicolumn{2}{|c|}{ With fixed effects } \\
\hline & [1] & [2] & [3] & [4] \\
\hline $\ln ($ Population) & $\begin{array}{l}0.737 \\
(3.82)^{* * *}\end{array}$ & $\begin{array}{l}0.777 \\
(4.04)^{* * *}\end{array}$ & $\begin{array}{l}1.238 \\
(0.50)\end{array}$ & $\begin{array}{c}-0.548 \\
(0.23)\end{array}$ \\
\hline$[\ln (\text { Population })]^{2}$ & $\begin{array}{l}-0.012 \\
(2.05)^{* *}\end{array}$ & $\begin{array}{l}-0.013 \\
(2.23)^{* *}\end{array}$ & $\begin{array}{c}-0.127 \\
(1.56)\end{array}$ & $\begin{array}{c}-0.106 \\
(1.34)\end{array}$ \\
\hline In (Per capita income $)$ & $\begin{array}{c}7.785 \\
(10.03)^{* * *}\end{array}$ & $\begin{array}{l}7.664 \\
(9.65)^{* * *}\end{array}$ & $\begin{array}{l}7.137 \\
(3.79)^{* * *}\end{array}$ & $\begin{array}{l}7.240 \\
(3.82)^{* * *}\end{array}$ \\
\hline$[\text { In (Per capita income) }]^{2}$ & $\begin{array}{l}-0.498 \\
(9.76)^{* * *}\end{array}$ & $\begin{array}{l}-0.492 \\
(9.44)^{* * *}\end{array}$ & $\begin{array}{l}-0.523 \\
(4.30)^{* * *}\end{array}$ & $\begin{array}{l}-0.526 \\
(4.29)^{* * *}\end{array}$ \\
\hline In(Infant mortality) & $\begin{array}{l}0.512 \\
(6.46)^{* * *}\end{array}$ & $\begin{array}{c}0.463 \\
(5.71)^{* * *}\end{array}$ & $\begin{array}{c}0.032 \\
(0.13)\end{array}$ & $\begin{array}{c}0.019 \\
(0.07)\end{array}$ \\
\hline In(Political and civil rights) & $\begin{array}{c}0.109 \\
(1.68)^{*}\end{array}$ & $\begin{array}{c}0.107 \\
(1.64)\end{array}$ & $\begin{array}{l}-0.257 \\
(1.98)^{* *}\end{array}$ & $\begin{array}{l}-0.275 \\
(2.10)^{* *}\end{array}$ \\
\hline Import duties revenue/tax revenue & $\begin{array}{l}-0.014 \\
(6.06)^{* * *}\end{array}$ & - & $\begin{array}{c}-0.009 \\
(1.61)\end{array}$ & - \\
\hline International trade tax revenue/tax revenue & - & $\begin{array}{l}-0.012 \\
(5.53)^{* * *}\end{array}$ & - & $\begin{array}{c}-0.005 \\
(0.88)\end{array}$ \\
\hline In(Multilateral aid) & $\begin{array}{l}0.166 \\
(6.33)^{* * *}\end{array}$ & $\begin{array}{l}0.158 \\
(5.86)^{* * *}\end{array}$ & $\begin{array}{l}0.086 \\
(3.51)^{* * *}\end{array}$ & $\begin{array}{c}0.088 \\
(3.62)^{* * *}\end{array}$ \\
\hline Recipient fixed effects & No & No & Yes & Yes \\
\hline Year dummies & Yes & Yes & Yes & Yes \\
\hline Estimated coefficients & 20 & 20 & 71 & 71 \\
\hline Wald chi-square & $1,745.43$ & $1,600.40$ & $4,121.71$ & $4,189.03$ \\
\hline Log likelihood & -734.99 & -738.44 & 524.33 & -526.12 \\
\hline Observations & 555 & 555 & 555 & 555 \\
\hline
\end{tabular}

likelihood-ratio tests, the fixed-effects model is the preferred specification. This further strengthens our finding that aid is not responsive to declining trade revenues in developing countries.

\section{CONCLUSION}

Although trade liberalization results in greater economic efficiency and growth, it is also a potential source of fiscal instability in developing countries because they rely heavily on revenue from trade taxes. There is a realization among developed nations that trade-related technical and financial assistance should be extended to mitigate detrimental effects of trade reforms in developing countries.

This article examines whether this trade revenue compensation motive is observed in donor behavior. We use aggregate bilateral aid data from 22 DAC countries to 52 aid-recipient countries over the 1991-2003 period. Using fixed effects to control for donors' political, strategic, and other considerations, we find no significant relationship between aid allocation decisions and trade revenues of recipient nations. This suggests that the governments of developing nations may face significant short-run challenges in the form of 
revenue constraints as a result of declining revenue collections from trade liberalization.

\section{REFERENCES}

Alesina, Alberto and Dollar, David. "Who Gives Foreign Aid to Whom and Why?" Journal of Economic Growth, March 2000, 5(1), pp. 33-63.

Bagwell, Kyle and Staiger, Robert W. "Reciprocity, Non-Discrimination and Preferential Agreements in the Multilateral Trading System." European Journal of Political Economy, June 2001, 17(2), pp. 281-325.

Bandyopadhyay, Subhayu and Wall, Howard, J. "The Determinants of Aid in the Post-Cold War Era." Federal Reserve Bank of St. Louis Review, November/December 2007, 89(6), pp. 553-47; http://research.stlouisfed.org/publications/review/ 07/11/Bandyopadhyay.pdf.

Baunsgaard, Thomas and Keen, Michael. "Tax Revenue and (or?) Trade Liberalization.” Working Paper No. WP/05/112, International Monetary Fund, June 2005; www.imf.org/external/pubs/ft/ wp/2005/wp05112.pdf.

Boschini, Anne and Olofsgård, Anders. "Foreign Aid: An Instrument for Fighting Communism?” Journal of Development Studies, 2007, 43(4), pp. 622-48.

Burnside, Craig and Dollar, David. "Aid, Policies, and Growth." American Economic Review, September 2000, 90(4), pp. 847-68.

Dollar, David and Levin, Victoria. "The Increasing Selectivity of Foreign Aid, 1984-2002.” World Bank Policy Research Paper 3299, World Bank Development Economics Group, May 6, 2004.

Dowling, J.M. and Hiemenz, Ulrich. "Biases in Allocation of Foreign Aid: Some New Evidence." World Development, April 1985, 13(4), pp. 535-41.

Dreher, Axel. "Does Globalization Affect Growth? Evidence from a New Index of Globalization." Applied Economics, 2006, 38(10), pp. 1091-110.
Dudley, Leonard and Montmarquette, Claude. "A Model of the Supply of Bilateral Aid." American Economic Review, 1976, 66(1), pp. 132-42.

Freedom House. Freedom in the World. New York: Freedom House, 2006.

International Monetary Fund. Government Finance Statistics (CD-ROM 2005). Washington, DC: International Monetary Fund, 2005.

International Monetary Fund. International Finance Statistics (CD-ROM 2004). Washington, DC: International Monetary Fund, 2004.

Lahiri, Sajal and Raimondos-Møller, Pascalis. "Competition for Aid and Trade Policy." Journal of International Economics, November 1997, 43(3-4), pp. 369-85.

Khattry, Barsha and Mohan Rao, J. "Fiscal Faux Pas? An Analysis of the Revenue Implications of Trade Liberalization." World Development, August 2002, 30(8), pp. 1431-44.

Kuziemko, Ilyana and Werker, Eric. "How Much Is a Seat on the Security Council Worth? Foreign Aid and Bribery at the United Nations." Journal of Political Economy, October 2006, 114(5), pp. 905-30.

Maddala, G.S. Econometrics. New York: McGraw-Hill, 1977.

Maizels, Alfred and Nissanke, Machiko, K. "Motivations for Aid to Developing Countries." World Development, September 1984, 12(9), pp. 879-900.

McKinlay, Robert D. and Little, Richard. "A Foreign Policy Model of U.S. Bilateral Aid Allocation." World Politics, 1977, 30(1), pp. 58-86.

McKinlay, Robert D. and Little, Richard. "The U.S. Aid Relationship: A Test of the Recipient Need and the Donor Interest Models.” Political Studies, June 1979, 27(2), pp. 236-50.

Neumayer, Eric. "The Determinants of Aid Allocation by Regional Multilateral Development Banks and United Nations Agencies.” International Studies Quarterly, 2003, 47(1), pp. 101-22. 
Organisation for Economic Co-operation and Development. "International Development Statistics Online, 2005.” Paris: OECD, 2005; www.oecd.org/ $\mathrm{dac} /$ stats/idsonline.

Rodrik, Dani. "The Limits of Trade Policy Reform in Developing Countries." Journal of Economic Perspective, Winter 1992, 6(1), pp. 87-105.

Sachs, J.D. and Warner, A.W. "Economic Reform and the Process of Global Integration." Brookings Papers on Economic Activity, 1995, 26(1), pp. 1-118.

Trumbull, William N. and Wall, Howard J. "Estimating Aid-Allocation Criteria with Panel Data." Economic Journal, July 1994, 104(425), pp. 876-82.

United Nations Conference on Trade and Development. "Handbook of Statistics Online, 2005." New York: UNCTAD, 2006; http://www.unctad.org/Templates/ webflyer.asp?docid=6558\&intItemID=1397\&lang=1 .
Wall, Howard J. "The Allocation of Official Development Assistance." Journal of Policy Modeling, June 1995, 17(3), pp. 307-14.

World Bank. "World Development Indicators 2006." Washington, DC: World Bank, 2006; http://devdata.worldbank.org/wdi2006/contents/ cover.htm.

Wooldridge, Jeffrey M. Introductory Econometrics. Mason, Ohio: South-Western Publishers, 2003.

Younas, Javed. "Motivation of Bilateral Aid Allocation: Altruism or Trade Benefits.” European Journal of Political Economy, September 2008, 24(3), pp. 661-74. 


\section{APPENDIX}

Data for Trade Tax Revenue Variables (Country Averages, 1991-2003, \$ Millions)

\begin{tabular}{|c|c|c|c|c|}
\hline Countries & $\begin{array}{l}\text { Real revenue from } \\
\text { ternational trade taxes }\end{array}$ & $\begin{array}{c}\text { Real revenue from } \\
\text { import duties }\end{array}$ & $\begin{array}{c}\text { Ratio of } \\
\text { international trade tax } \\
\text { to total tax revenue }\end{array}$ & $\begin{array}{c}\text { Ratio of } \\
\text { import duties revenue } \\
\text { to total tax revenue }\end{array}$ \\
\hline Algeria & $2,021.8$ & $2,021.8$ & 16.2 & 16.2 \\
\hline Argentina & $2,122.6$ & $1,685.4$ & 13.8 & 10.3 \\
\hline Bhutan & 1.2 & 0.9 & 4.4 & 3.2 \\
\hline Bolivia & 67.7 & 67.7 & 9.5 & 9.5 \\
\hline Botswana & 279.5 & 279.4 & 35.4 & 35.4 \\
\hline Brazil & $2,534.6$ & $2,533.8$ & 5.5 & 5.5 \\
\hline Bulgaria & 183.9 & 165.7 & 10.4 & 9.2 \\
\hline Burundi & 35.5 & 25.2 & 26.2 & 18.5 \\
\hline Cameroon & 310.0 & 263.3 & 33.0 & 27.6 \\
\hline China & $5,552.2$ & $5,552.2$ & 13.6 & 13.6 \\
\hline Colombia & 820.5 & 813.1 & 10.3 & 10.1 \\
\hline Congo DR & 79.5 & 73.5 & 35.3 & 31.0 \\
\hline Côte d'Ivoire & $1,124.9$ & 640.6 & 60.4 & 34.1 \\
\hline Croatia & 491.8 & 491.8 & 13.0 & 13.0 \\
\hline Dominican Republic & 872.0 & 820.6 & 43.7 & 41.0 \\
\hline Ethiopia & 247.8 & 188.0 & 35.7 & 27.4 \\
\hline Hungary & $1,119.8$ & $1,119.8$ & 12.3 & 12.3 \\
\hline India & $9,643.6$ & $9,540.5$ & 28.5 & 28.1 \\
\hline Indonesia & $1,126.5$ & $1,041.3$ & 4.9 & 4.5 \\
\hline Jordan & 436.3 & 409.1 & 33.6 & 31.6 \\
\hline Kenya & 321.0 & 321.0 & 16.0 & 16.0 \\
\hline Latvia & 29.3 & 29.3 & 3.4 & 3.4 \\
\hline Lithuania & 43.7 & 43.0 & 4.8 & 4.6 \\
\hline Madagascar & 174.8 & 167.3 & 54.6 & 51.7 \\
\hline Malaysia & $1,839.5$ & $1,536.4$ & 13.1 & 10.9 \\
\hline Maldives & 40.6 & 40.1 & 64.1 & 62.9 \\
\hline Mauritius & 259.7 & 251.4 & 40.8 & 39.3 \\
\hline
\end{tabular}

SOURCE: Government Finance Statistics (IMF, 2005) and World Development Indicators (World Bank, 2006). 


\section{APPENDIX, cont'd}

Data for Trade Tax Revenue Variables (Country Averages, 1991-2003, \$ Millions)

\begin{tabular}{|c|c|c|c|c|}
\hline Countries & $\begin{array}{c}\text { Real revenue from } \\
\text { nternational trade taxes }\end{array}$ & $\begin{array}{l}\text { Real revenue from } \\
\text { import duties }\end{array}$ & $\begin{array}{c}\text { Ratio of } \\
\text { international trade tax } \\
\text { to total tax revenue }\end{array}$ & $\begin{array}{c}\text { Ratio of } \\
\text { import duties revenue } \\
\text { to total tax revenue }\end{array}$ \\
\hline Mexico & $2,977.3$ & $2,971.2$ & 7.1 & 7.0 \\
\hline Moldova & 20.9 & 14.5 & 9.5 & 6.3 \\
\hline Morocco & $1,407.9$ & $1,405.8$ & 20.5 & 20.5 \\
\hline Nepal & 119.6 & 118.0 & 32.7 & 32.4 \\
\hline Nicaragua & 54.9 & 54.9 & 14.9 & 14.9 \\
\hline Oman & 129.6 & 129.6 & 12.3 & 12.3 \\
\hline Pakistan & $1,766.4$ & $1,766.4$ & 26.6 & 26.6 \\
\hline Papua New Guinea & 259.4 & 196.7 & 30.5 & 23.5 \\
\hline Paraguay & 152.8 & 150.9 & 20.1 & 19.7 \\
\hline Peru & 750.7 & 747.7 & 12.6 & 12.5 \\
\hline Philippines & $2,559.4$ & $2,545.9$ & 25.8 & 25.7 \\
\hline Poland & $2,306.7$ & $2,306.7$ & 8.1 & 8.1 \\
\hline Romania & 406.5 & 404.8 & 7.7 & 7.6 \\
\hline Seychelles & 103.7 & 103.7 & 68.6 & 68.6 \\
\hline Sierra Leone & 30.7 & 30.3 & 44.8 & 44.2 \\
\hline South Africa & 842.9 & 810.6 & 2.9 & 2.8 \\
\hline Sri Lanka & 405.7 & 398.8 & 19.9 & 19.5 \\
\hline $\begin{array}{l}\text { St. Vincent and } \\
\text { the Grenadines }\end{array}$ & 33.9 & 33.1 & 46.6 & 45.6 \\
\hline Syria & $1,274.0$ & $1,061.8$ & 14.8 & 12.3 \\
\hline Thailand & $3,083.6$ & $3,080.9$ & 15.7 & 15.7 \\
\hline Tunisia & 967.2 & 947.7 & 28.3 & 27.8 \\
\hline Uruguay & 201.3 & 178.3 & 7.5 & 6.6 \\
\hline Venezuela & $1,336.3$ & $1,332.4$ & 12.4 & 12.4 \\
\hline Yemen & 337.2 & 334.9 & 29.5 & 29.3 \\
\hline Zimbabwe & 281.1 & 277.3 & 19.1 & 18.9 \\
\hline
\end{tabular}

SOURCE: Government Finance Statistics (IMF, 2005) and World Development Indicators (World Bank, 2006). 
